\title{
Factors affecting Lychee supply chain linkage and business performance
}

\author{
Pham Thi Dinh ${ }^{a^{*}}$, Mai Thi Huyen ${ }^{a}$, Nong Huu Tunga, Bui Anh Tu ${ }^{\mathrm{b}}$ and Pham Van Hung
}

${ }^{a}$ Bac Giang Agriculture and Forestry University, Vietnam

${ }^{b}$ Thuy Loi University, Vietnam

${ }^{c}$ Vietnam National University of Agriculture, Vietnam

A B S T R A C T

Article history:

Received July 18, 2021

Received in revised format

September 24, 2021

Accepted October 202021

Available online

October 232021

Keywords:

Supply chain linkages

Quality management

Business performance

Lychee supply chain

\begin{abstract}
The objective of this study is to investigate the relationship between supply chain linkage and business performance in the lychee supply chain in Vietnam. The study collected 395 matched samples after sample screening. Partial least squares (PLS) algorithm is used to process the data. Research results show a link between supply chain linkage and business performance. Furthermore, research shows that risk supply chain, quality management, and business strategy also impact supply chain linkages and business performance.
\end{abstract}

\section{Introduction}

When companies recognize the advantages of joining and collaborating, supply chain management becomes more focused (Spekman et al., 1998). Organizations will tend to enhance collaboration with other supply chain participants to utilize resources as the economy expands and specialization rises (Lazzarini, 2001). Having a partner's quality at a cheaper cost than inefficient self-production as a result, businesses are becoming more intertwined to better manage supply and distribution networks, reduce costs, and improve customer satisfaction, all of which contribute to increased productivity (Birachi, 2006). Participating firms' competitiveness and profitability will be improved. As a result, many academics agree that rivalry happens between supply networks and supply chains, rather than between companies and firms (Osarenkhoe, 2010).

Supply chain management has been characterized by many academics and business leaders as the link between basic business operations from the ultimate consumer to the primary supplier, delivering products, services, and information to maximize added value for consumers and supply chain companies (Ellram \& Cooper, 1990; Mabert \& Venkataramanan, 1998; Robinson \& Malhotra, 2005). To establish a sustained competitive advantage, supply chain management is the management of all operations linked to the movement and transformation of goods and information from raw materials to the ultimate customer (Felea \& Albăstroiu, 2013; Tracey et al., 2005). There are many levels of supply chain connections, ranging from loose to closely coupled.

Many academics have attempted to uncover and define preconditions for supply chain linking participants concerned with the supply chain (supply, market, information, and environment) (Christopher \& Jüttner, 2000). Many academics ascribe supply chain links to global competitive pressures or environmental concerns, such as changes in supply, demand, and technology, as well as new market possibilities (Jüttner et al., 2007). Other external constraints, such as hazards connected

* Corresponding author

E-mail address: ptdinh8888@gmail.com (P. T. Dinh)

(C) 2022 Growing Science Ltd. All rights reserved.

doi: $10.5267 /$ j.uscm.2021.10.011 
with the supply chain, and internal variables, according to specialists in the seafood industry and worldwide competitive pressure, have a major influence on the degree of connection between members in the supply chain. One of the most important elements affecting the amount of collaboration with partners — supply chain members — is the company's business plan.

\section{Literature review}

\subsection{Risk supply chain}

Risk influences the degree of connection, which is consistent with the environment-organization link (Ellis et al., 2011). When the climate changes, the organization must adjust as well to survive and grow. Organizations seek to strengthen partnerships to reduce the impact of supply, demand, technology, and the environment in general on supply, demand, and technology (Saberi et al., 2019). However, there are differing perspectives on this connection. According to some writers, the more unstable and hazardous the environment is, the more organizations tend to deepen their ties. Meanwhile, some other studies have found an opposite relationship: the higher the risk, the less likely companies are to connect with one another; instead, they build normal ties with other businesses' partners to adjust when the environment changes fast (Hallikas et al., 2004; Shimizu \& Hitt, 2004). As a result, a more detailed explanation of this relationship is required.

\subsection{Business strategy}

The relationship between design, structure, and company success is also consistent with the influence of corporate strategy on supply chain links (Cagliano et al., 2006). According to this idea, strategy is the driving force for change in corporate structures and processes, and it has an impact on outcomes. However, it remains to be seen which system will push the company to enhance supply chain links and how their relationship affects business results (Byrd \& Davidson, 2003). To put it another way, determining whether changing organizational structure in the direction of increasing supply chain linkage is appropriate for what type of business strategy, or a combination of many designs from which to improve business efficiency, is still a problem that needs to be researched and explained.

\subsection{Quality management}

Suppliers, manufacturers, and consumers are all part of a typical supply chain (Ambe \& Badenhorst-Weiss, 2010). The goal of supply chain management is to create a link between a product's complete manufacturing and distribution networks to confirm or fulfill consumer needs (Van Der Vorst \& Beulens, 2002; Tracey et al., 2005). Product quality, pricing, product line, order fill rate, order cycle time, shipment information, and delivery frequency are examples of such criteria. One of the most essential methods to respond quickly, properly, and profitably to market needs is through quality management. The link between quality management methods used by suppliers and organizational success is yet unknown.

\subsection{Supply chain linkages}

Bechtel and Jayaram (1997) divided four different schools of thought on supply chain linkage: (1) functional chain awareness school; (2) linkage/logistics school; (3) information school; and (4) integration/process school.

The relationship between an organization's commercial success and supply chain links is examined from a resource-based theoretical approach. The relationship between supply chain links and an organization's business success has been examined to various degrees. Linkage, in the context of the supply chain, refers to connections with suppliers and customers. On a logistical level, the phrase can also relate to the connection between the customer and the seller. Most of the studies show that external linkages have an influence on a company's business performance. The financial and marketing performance of a company are immediately and long-term influenced by supply chain management and alignment.

Based on empirical studies and theories, the research hypotheses are:

$\mathbf{H}_{1}$ : Risk supply chain has a positive effect on supply chain linkages.

$\mathbf{H}_{2}$ : Risk supply chain has a positive effect on business performance.

$\mathbf{H}_{3}$ : Business strategy has a positive effect on supply chain linkages.

H4: Business strategy has a positive effect on business performance.

H5: Quality management has a positive effect on supply chain linkages.

H6: Quality management has a positive effect on business performance.

$\mathbf{H}_{7}$ : Supply chain linkages has a positive effect on business performance. 


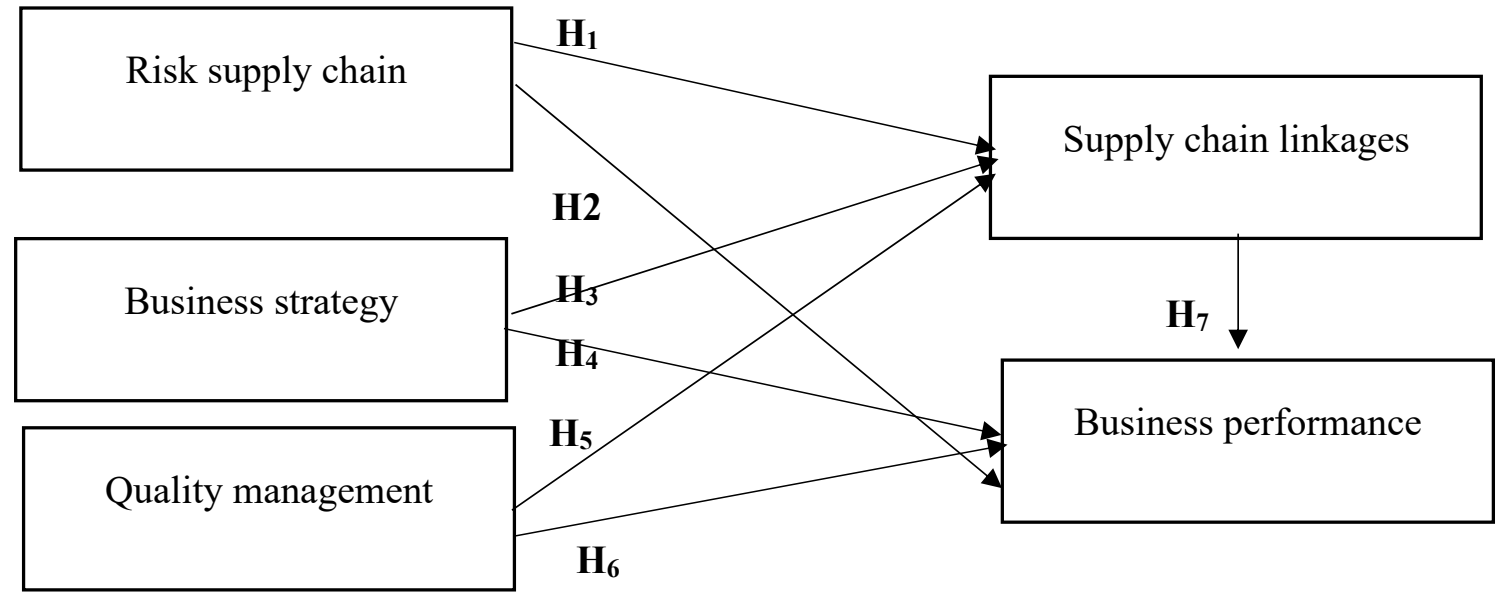

Fig. 1. Model Concept

\section{Methodology}

We created an internet survey to measure the constructs, with responses graded on a five-point Likert scale $(1=$ Strongly Disagree; $5=$ Strongly Agree). We utilized the partial least squares approach to analyze these results statistically. We received 420 replies, with a total of 395 legitimate questionnaires after filtering the data. This sample size is suitable for the model's conditions. The sample size must meet the so-called "rule of thumb" which states that the sample size must be at least ten times bigger than the number of predictors (Gefen et al., 2011).

\section{Results}

Testing the reliability test construct using composite reliability (CR), average variable extracted (AVE), and Cronbach alpha is 0.50 or more (Hair et al., 2014) shown in Table 2.

Table 2

Test of the validity and reliability

\begin{tabular}{|c|c|c|c|}
\hline Code & Variable & Factor's loading & VIF \\
\hline \multicolumn{4}{|c|}{ Risk supply chain (Cronbach's alpha: 0.761, CR: 0.845, AVE: 0.578) } \\
\hline $\mathrm{R} 1$ & Supply risk & 0.736 & 1.272 \\
\hline $\mathrm{R} 2$ & Market risk & 0.800 & 2.111 \\
\hline R3 & Information risk & 0.725 & 1.915 \\
\hline R4 & Environmental risk & 0.778 & 1.499 \\
\hline \multicolumn{4}{|c|}{ Business strategy (Cronbach's alpha: 0.879, CR: 0.925, AVE: 0.805) } \\
\hline $\mathrm{S} 1$ & Cost strategy & 0.919 & 2.932 \\
\hline $\mathrm{S} 2$ & Customer strategy & 0.877 & 2.242 \\
\hline S3 & Mixed strategy & 0.895 & 2.387 \\
\hline \multicolumn{4}{|c|}{ Quality management (Cronbach's alpha: 0.775, CR: 0.870, AVE: 0.691) } \\
\hline Q1 & Product Standards (GAP) & 0.866 & 1.791 \\
\hline Q2 & Production process & 0.797 & 1.462 \\
\hline Q3 & Shipping process & 0.829 & 1.662 \\
\hline \multicolumn{4}{|c|}{ Supply chain linkages (Cronbach's alpha: 0.831, CR: 0.888, AVE: 0.666) } \\
\hline L1 & Linkages between farmer households & 0.715 & 1.446 \\
\hline L2 & Linking farmer households and suppliers & 0.810 & 1.833 \\
\hline L3 & Linkage between farmer households and purchasing enterprises & 0.876 & 2.671 \\
\hline L4 & Link between purchasing businesses and customers & 0.854 & 2.370 \\
\hline \multicolumn{4}{|c|}{ Business performance (Cronbach's alpha: 0.758, CR: 0.861, AVE: 0.674) } \\
\hline B1 & Revenue & 0.809 & 1.427 \\
\hline $\mathrm{B} 2$ & Profit & 0.800 & 1.555 \\
\hline B3 & Cost & 0.852 & 1.761 \\
\hline
\end{tabular}

So, the overall evaluation research model can be expressed well, and we can further proceed with the analysis of hypothesis testing. 


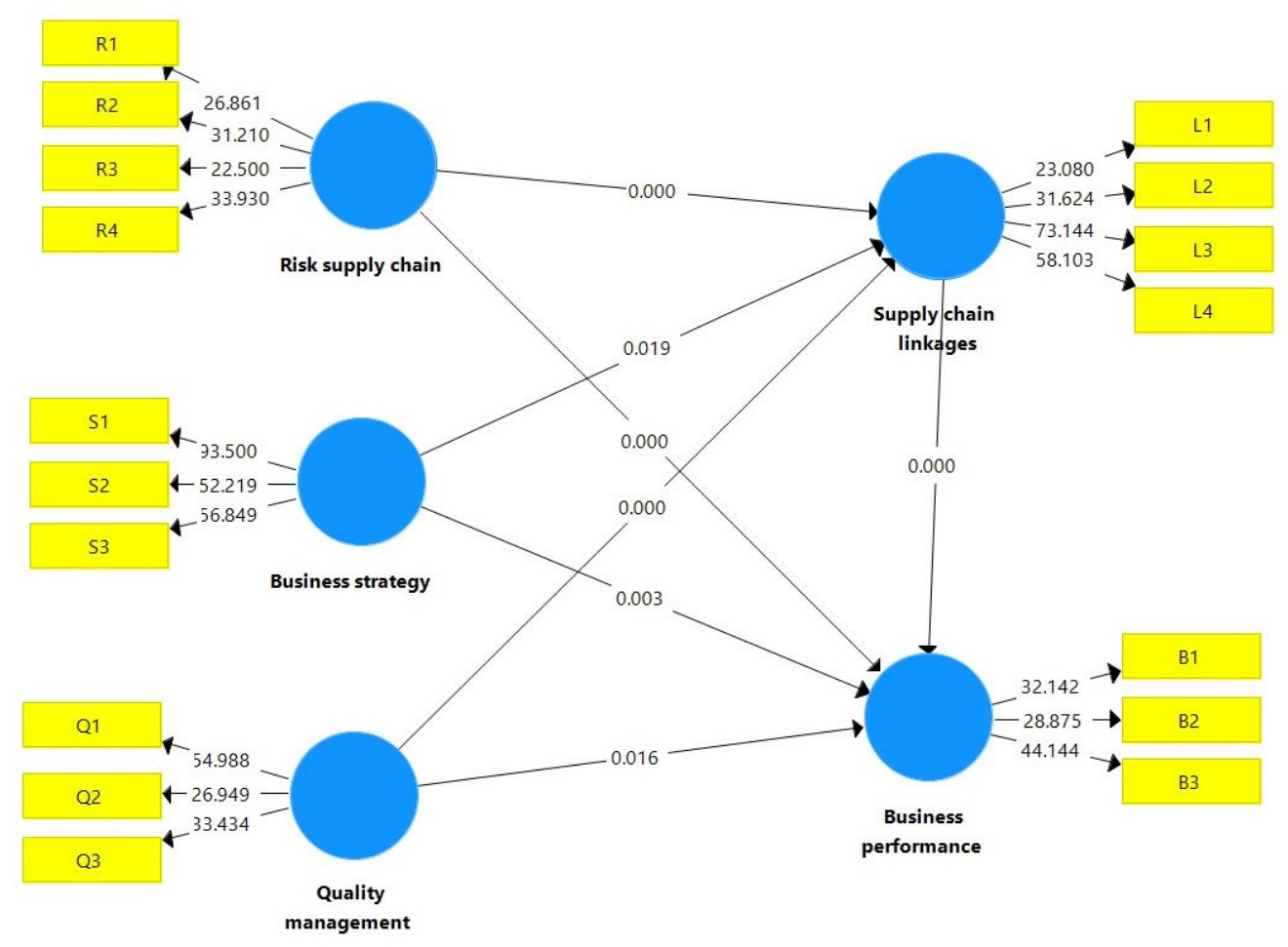

Fig. 2. Bootstrapping Result

Table 3

Test Results Path Coefficient

\begin{tabular}{llcl}
\hline \multicolumn{1}{c}{ Hypothesis Test } & P_value & Results \\
\hline H1 & Risk supply chain $\rightarrow$ Supply chain linkages & 0.000 & Supported \\
H2 & Risk supply chain $\rightarrow$ Business performance & 0.000 & Supported \\
H3 & Business strategy $\rightarrow$ Supply chain linkages & 0.019 & Supported \\
H4 & Business strategy $\rightarrow$ Business performance & 0.003 & Supported \\
H5 & Quality management $\rightarrow$ Supply chain linkages & 0.000 & Supported \\
H6 & Quality management $\rightarrow$ Business performance & 0.016 & Supported \\
H7 & Supply chain linkages $\rightarrow$ Business performance & 0.000 & Supported \\
\hline
\end{tabular}

Based on the results of the direct relationship analysis from Table 3, it indicates that the hypothesis $(\mathrm{H} 1, \mathrm{H} 2, \mathrm{H} 3, \mathrm{H} 4, \mathrm{H} 5, \mathrm{H} 6$ and $\mathrm{H} 7$ are accepted).

\section{Conclusion}

Research results have shown that risk variables in the supply chain impact supply chain linkages, including risks from supply sources and risks from the market, risks from information sources. Specifically, sourcing risk was negatively related to supplier linkage. This is consistent with the studies' view, but it is contrary to the theory of the relationship between environment and organization. In contrast, this theory states: the more unstable the environment, the more businesses need to strengthen linkages to limit that instability. The results of this study also have indicated that sourcing risk had no impact on customer linkage. This contrasts with the results of previous studies. Market risks had an impact on relationships with both customers and suppliers. Risks from information sources only affect the level of linkages between enterprises and suppliers. In addition, environmental risks produce surprising results when there is no impact on supply chain linkages. This result completely contradicts the results of previous studies. Ultimately, supply chain alignment, in turn, has had a positive impact on business results. The results in this case study are also consistent with previous studies that suggest that forms of association with suppliers and with customers both affect business results. The above results have shown that managers need to pay more attention to risk management in the supply chain, especially from supply sources, market risks, and information sources. Effective risk management will help improve the relationship between partners in the supply chain and improve production and business efficiency. 


\section{References}

Ambe, I. M., \& Badenhorst-Weiss, J. A. (2010). Strategic supply chain framework for the automotive industry. African Journal of Business Management, 4(10), 2110-2120.

Bechtel, C., \& Jayaram, J. (1997). Supply chain management: a strategic perspective. The International Journal of Logistics Management, 8(1), 15-34.

Birachi, E. (2006). Determinants of coordination and supply chain performance The case of fresh milk supply chains in Kenya (Doctoral dissertation).

Byrd, T. A., \& Davidson, N. W. (2003). Examining possible antecedents of IT impact on the supply chain and its effect on firm performance. Information \& Management, 41(2), 243-255.

Cagliano, R., Caniato, F., \& Spina, G. (2006). The linkage between supply chain integration and manufacturing improvement programmes. International Journal of Operations \& Production Management, 26(3).

Christopher, M., \& Jüttner, U. (2000). Developing strategic partnerships in the supply chain: a practitioner perspective. European Journal of Purchasing \& Supply Management, 6(2), 117-127.

Ellis, S. C., Shockley, J., \& Henry, R. M. (2011). Making sense of supply disruption risk research: A conceptual framework grounded in enactment theory. Journal of Supply Chain Management, 47(2), 65-96.

Ellram, L. M., \& Cooper, M. C. (1990). Supply chain management, partnership, and the shipper-third party relationship. The International Journal of Logistics Management, 1(2), 1-10.

Felea, M., \& Albăstroiu, I. (2013). Defining the concept of supply chain management and its relevance to Romanian academics and practitioners. Amfiteatru Economic Journal, 15(33), 74-88.

Hallikas, J., Karvonen, I., Pulkkinen, U., Virolainen, V. M., \& Tuominen, M. (2004). Risk management processes in supplier networks. International Journal of Production Economics, 90(1), 47-58.

Jüttner, U., Christopher, M., \& Baker, S. (2007). Demand chain management-integrating marketing and supply chain management. Industrial Marketing Management, 36(3), 377-392.

Lazzarini, S., Chaddad, F., \& Cook, M. (2001). Integrating supply chain and network analyses: the study of netchains. Journal on Chain and Network Science, 1(1), 7-22.

Mabert, V. A., \& Venkataramanan, M. A. (1998). Special research focus on supply chain linkages: challenges for design and management in the 21 st century. Decision sciences, 29(3), 537-552.

Osarenkhoe, A. (2010). A study of inter-firm dynamics between competition and cooperation-A coopetition strategy. Journal of Database Marketing \& Customer Strategy Management, 17(3), 201-221.

Robinson, C. J., \& Malhotra, M. K. (2005). Defining the concept of supply chain quality management and its relevance to academic and industrial practice. International Journal of Production Economics, 96(3), 315-337.

Saberi, S., Kouhizadeh, M., Sarkis, J., \& Shen, L. (2019). Blockchain technology and its relationships to sustainable supply chain management. International Journal of Production Research, 57(7), 2117-2135.

Shimizu, K., \& Hitt, M. A. (2004). Strategic flexibility: Organizational preparedness to reverse ineffective strategic decisions. Academy of Management Perspectives, 18(4), 44-59.

Spekman, R. E., Kamauff, J. W., \& Myhr, N. (1998). An empirical investigation into supply chain management: a perspective on partnerships. Supply Chain Management: An International Journal, 3(2), 53-67.

Tracey, M., Lim, J. S., \& Vonderembse, M. A. (2005). The impact of supply-chain management capabilities on business performance. Supply Chain Management: An International Journal, 10(3), 179-191.

Tracey, M., Lim, J. S., \& Vonderembse, M. A. (2005). The impact of supply-chain management capabilities on business performance. Supply Chain Management: An International Journal, 10(3), 179-191.

Van Der Vorst, J. G., \& Beulens, A. J. (2002). Identifying sources of uncertainty to generate supply chain redesign strategies. International Journal of Physical Distribution \& Logistics Management, 32(6), 409-430. 
(C) 2022 by the authors; licensee Growing Science, Canada. This is an open access article distributed under the terms and conditions of the Creative Commons Attribution (CCBY) license (http://creativecommons.org/licenses/by/4.0/). 